\title{
Technology Adoption and the Banking Agency in Rural Kenya
}

\author{
Nganga, Stephen Irura (PhD) \\ Associate Professor and Dean, school of Business, Karatina University, Karatina, Kenya \\ Mwachofi, Magdalene Munjiru \\ Lecturer, Eldoret polytechnic, Eldoret and an Entrepreneur Likuyani, Kenya
}

Accepted: March 17, 2013 Published: April 24, 2013

Doi:10.5296/jsr.v4i1.3584 URL: http://dx.doi.org/10.5296/jsr.v4i1.3584

\begin{abstract}
The paper looks at the ways of approaching the promotion of Mobile and Agency Banking technology adoption and its diffusion in Kenya. Technology adoption climates in developing countries are, by nature, problematic, characterized by poor business and governance conditions, low educational levels, and inappropriate infrastructure. The paper is informed by comparative survey data obtained from SMEs and Bank Agents in Karatina and Likuyani, both districts in rural set ups in Kenya. The study establishes that though a variety of mobile and agency banking services are on offer, only a very small proportion of customers who access it, actually use it. The paper recommends intervention addressing both internal and external factors that inhibit mobile and agency banking technology adoption to the full in rural Kenya and other similar developing countries.
\end{abstract}

Keywords: Mobile and Agency Banking; Technology Adoption

\section{Introduction}

A financial revolution is in progress. It is not happening under the skyscrapers of New York or on the streets of London. It is not taking place in Beijing or Mumbai but in the slums of Nairobi and in the markets of Kisumu (Mas, 2010). Information and communication technologies (ICT) fuel the greatest wave of technical innovation currently spreading across the globe, affecting new areas of social and economic activity. Unsurprisingly, financial businesses everywhere have been in the throes of organizational changes and innovation based on new possibilities opened up by ICT. Money, after all, is "just" information about who owes what to whom. Much innovation happens in advanced economies yet new technology has the potential to unleash radical change in developing economies.

By its very nature the ICT phenomenon is relatively new in the developing world. Available 
data, suggest that the majority of developing countries such as Kenya in sub-Saharan Africa are lagging behind in the information revolution (Zhao and Frank, 2003). Not surprisingly, the quest for adoption of ICT in educational management has been problematic and will require fundamental shifts in the regulatory environment, as well as renewed attention to public-private partnerships and social services. For example, developed countries have 80 per cent of the world's Internet users, while the total international bandwidth for all of Africa is less than that of the city of São Paulo, Brazil (Campbell and Sellbum, 2002). There is little doubt that sub-Saharan Africa's populations are missing out on the boons of information and communication technology (ICT) (Bigum, 2000).

The BECTA Report (2003) identifies the key barriers to using technology as: Lack of access to appropriate ICT equipment, Lack of time for training, exploration and preparation, Lack of models of good practice in ICT, Negative attitudes towards ICTs in education, Technology anxiety and a lack of confidence, Fear of change and a lack of personal change management skills, Unreliable equipment and Lack of technical, administrative and institutional support. BECTA (2003) report further classifies the barriers into the four factors namely a) resource-related factors b) factors associated with training, skills, knowledge and computer experience c) attitudinal and personality factors, and d) cultural factors. Mobile banking is in its initial stages in Kenya. Kenya, is a developing country with a total population of 43 million people, with slightly lower than average income inequality measured by the Gini Coefficient at 47.7 compared to South Africa's Gini coefficient 57.8; Brazil's 55.0; Peru's 49.6, Mexico's 48.1 and India's 36.8 (UNDP, 2009). This population needs continuous cash flow for development and mobile banking has been making waves. Mobile banking offers numerous benefits to SMEs. SMEs can check account balances, transfer money, pay bills, collect receivables and ultimately reduce transaction costs and establish greater control over bank accounts.

Financial security through saving is a key component in any development endeavor as it is believed to be the surest way of increasing income and boosting productivity in an attempt to break through the vicious cycle of poverty. High incomes lead to alleviation of poverty in households, ultimately resulting into improved quality of life of people in rural communities. High levels of gross national savings reduce a country's reliance on and exposure to the unpredictable global capital market. In Kenya, unfortunately, the savings levels are rather low, which makes the country dependent on foreign investment to finance the capacity for future growth, Pettigrew et al (2007). Such dependency is not always healthy, as foreign investors often withdraw at the slightest hint of bad news. At an individual level, curbing excessive consumption and making provision for personal future well-being is necessary both for maintaining and improving the quality of life, as well as for relieving the burden to provide.

\section{Statement of the Problem}




\section{Mll Macrothink}

Journal of Sociological Research

ISSN 1948-5468

2013, Vol. 4, No. 1

The Kenyan rural population has remained largely unbanked. Rural entrepreneurs' access to banking services in these areas has been hindered by the assumption that rural populations have low incomes which are not sufficient to sustain banking operations; hence most formal banks in Kenya have shied away from offering banking services to rural areas for many years. Recently, commercial banks in Kenya in collaboration with the mobile phone service providers came up with the new innovation of mobile and agency banking. Given the potential for the transformative impact of such a service to the rural population, despite the known impact, most of Kenyan Small and Micro Enterprises (SMEs) owners are still not utilizing the mobile banking to the full potential if used at all. The question that begs for answer and requires immediate intermediation is what ails adoption of this type of technology. This question motivated and guided the researchers to conduct this study focusing technology adoption and agency banking by looking at the factors causing difference in two areas Karatina and Likuyani which are rural in nature.

\section{Literature and Conceptual Base}

About 79 per cent of Kenya's population live in rural areas and relies on agriculture for most of its income (IFAD, 2011). The rural economy depends mainly on subsistence agriculture, which produces 75 per cent of total agricultural output. Most Kenyans live in areas that have well to high potential for agriculture, and comprise about 18 per cent of the country's territory and are located in the central and western areas of the country (IFAD, 2011). Kenya launched its long-term development blueprint, Vision 2030, in 2008. The blueprint aims to create a "globally competitive and prosperous country with a high quality of life by 2030 ". Vision 2030 is designed to guide the country towards meeting the Millennium Development Goals by 2015 and beyond whose aim is to transform Kenya into "a newly industrialized, middle-income country". The entrepreneur and in particular, in Least Developed Countries (LDCs), the micro and small scale enterprise owners have to play a significant role in the realization of this goal.

Kenya recognizes that the entrepreneur in the community is a primary contributor and mobilizer of resources to develop the economy, a provider of employment for others and a stabilizing factor in society (GOK, 1992). Growth of the economy is achieved by increases in productivity and full absorption of all available resources into productive use (Gibb, 1988). SMEs act as providers of locally demanded goods and have the ability to develop and use appropriate technology (Gibb, 1988). Innovation is therefore a crucial part of the entrepreneurial process (Wickman, 2006). Since the late 1970s when the personal computer was introduced, an information technology (IT) revolution has been evident. Companies have networks of personal computers linked to one another, to the firm's central computers and to their customers and suppliers. This has provided bank customers with electronic access to account information such as account balances, deposit and withdrawal of money. IT has also allowed customers to shop in faraway places from the comfort of their homes (Besley and Brigham, 2005). Mobile phones have done even better, since they allow customers access to the internet through their phones wherever they may be since mobile phones are portable. 
In 2007 Kenya pioneered the mobile banking business with the introduction of M-Pesa, the mobile money-transfer service that revolutionized banking (Mulupi, 2011). The mobile-banking sector has created thousands of jobs since then through the hiring of agents and brought millions of previously unbanked Kenyans to the formal banking sector. Populations in rural Kenya have limited access to banking services due to insufficient branch networks in these locations. Mobile financial services offer efficiency and are time and cost saving for people who have to travel long distances to access a physical bank branch. The introduction of new mobile banking platforms has extended the benefits of mobile banking to more Kenyans (Mulupi, 2011).

Agency banking is the new innovation that banks are using to take services to the un-banked and under-banked at a cheaper rate. Agency banking was introduced during the 2009 budget and was enshrined in the Finance bill of 2009. Agency banking takes customers out of the bank halls to kiosks and villages. Investors have pumped billions into new platforms that offer agency banking services (Mulupi, 2011). Among the platforms are M-kesho and 24/7 from Equity bank, Tangaza and Mobikash of MobiKash Afrika Limited, Co-op kwa jirani of Co-operative bank among others. Given that more Kenyans without bank accounts will gain access to mobile banking services, transaction fees charged to mobile banking customers have reduced. One notable feature mobile platforms share is that their agents also serve as banking agents (Mulupi, 2011).

The platforms also offer a wide range of financial services including money transfer, mobile banking and mobile payments and push access to banking services among Kenya's rural communities. The Mobicash platform for instance allows customers to link up to 15 bank accounts to their mobile wallet. To bring the unbanked and semi-banked (Kenyans who have mobile money accounts but lack real bank accounts), to the formal banking platform, MobiKash also offers a universal bank account, dubbed POPOTE, through which customers can open an account in any of its partner banks. Currently the platform is connected to three banks: Post Bank, National Bank of Kenya and the Trans National Bank (Mulupi, 2011). The mobile platforms are widely expected to lead to regional and national economic growth due to the increased access to advanced financial services by those who need it the most; the unbanked and semi-banked. Since traditional barriers to commerce like access, cost and time have been eliminated; economic growth is set to hasten with independent, real-time and unencumbered access to financial services (Mulupi, 2011).

Businesses with strong cash flows have benefited from the newly-introduced agency banking. Equity Bank, for example, has scaled up from having 80 branches, to sell its products through 17,000 agents of M-pesa. The Bank projected that it would open 20,000 Agency Banking Locations in the 1st Quarter of 2011 creating some 100,000 jobs. According to James Mwangi the Chief Executive Officer of the bank, the bank borrowed the concept from Brazil, the only country in the world with a successful agency banking model. By June 2011, over 30,000 outlets around the country had been enrolled as mobile money transfer agents. These 


\section{Ml Macrothink}

left banks with a smaller pool of businesses from which they could pick the cash-rich operations they needed to roll out the agency banking model (Kinyanjui, 2011). Many of the agencies are located in rural areas where, despite the advent of mobile phone money services, people still walk long distances to transact over-the-counter business. There is still cases of selected use even when a client has chosen to embrace the new technology, they still use some and rely on the traditional methods they are used to for some activities despite the fact that it could also be done through mobile and agency banking. This suggests apathy in technology adoption.

\section{Technology Acceptance Model (TAM)}

There are several models existing that have been used to investigate adoption of technology. Several studies focusing on adoption of mobile services have their roots in Technology Acceptance Model (TAM) originally proposed by Davies in 1986. The model is originally designed to predict user's acceptance of Information Technology and usage in an organizational context. TAM focuses on the attitude explanations of intention to use a specific technology or service; it has become a widely applied model for user acceptance and usage. There are a number of meta-analyses on the TAM that have demonstrated that it is a valid, robust and powerful model for predicting user acceptance (Bertrand and Bouchard, 2008). TAM, shown in figure 1 was also the first model that established external variables (shown as $\mathrm{X}_{1}, \mathrm{X}_{2}$ and $\mathrm{X}_{3}$ in figure 1) as key factors in studying technology adoption.

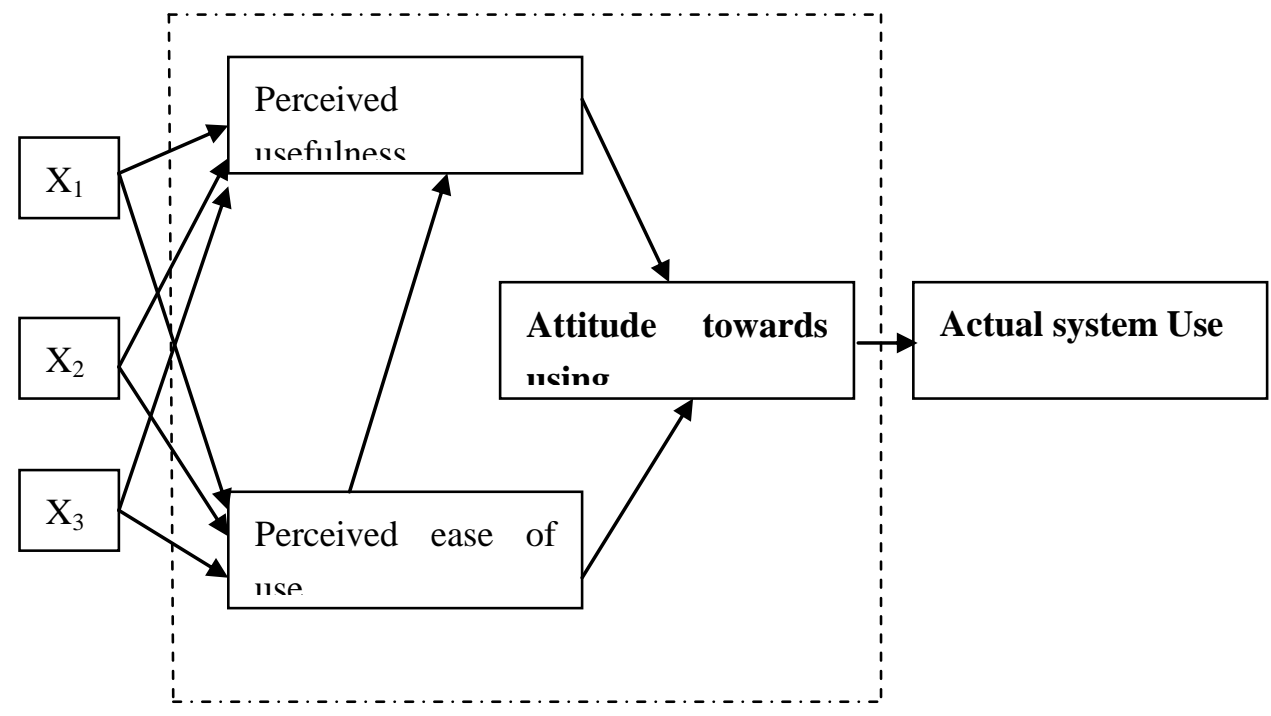

Figure 1: Technology Acceptance Model

Source: (Davis, 1989)

The TAM model which deals with perceptions as opposed to real usage, suggests that when users are presented with a new technology, two important factors influence their decision about how and when they will use it (Davis, 1989). These key factors are: 
- Perceived usefulness (PU) - This was defined by Davis as "the degree to which a person believes that using a particular system would enhance his or her job performance".

- Perceived ease-of-use (PEoU) - Davis defined this as "the degree to which a person believes that using a particular system would be free from effort"

\section{Conceptual framework for the study}

Previous research has suggested that trust-related constructs and resource related constructs should be the critical antecedents of the behavioral intention to use information systems. Based on the information systems acceptance literature, especially the extended TAM by Luarn \& Lin, (2004), this research adopts the research model indicated in Figure 2. As noted by Davis (1989), future research of Information System and Information Technology usage has to address the other variables which affect usefulness, ease of use and user acceptance. This study sought to find technology adoption difference and agency banking factors causing this difference; resource-related factors, factors associated with training, skills, knowledge and computer experience, attitudinal and personality factors, and cultural factors. Based on the above arguments, this research integrates TAM with four additional variables shown in figure 2 to investigate adoption of technology in mobile and agency banking.

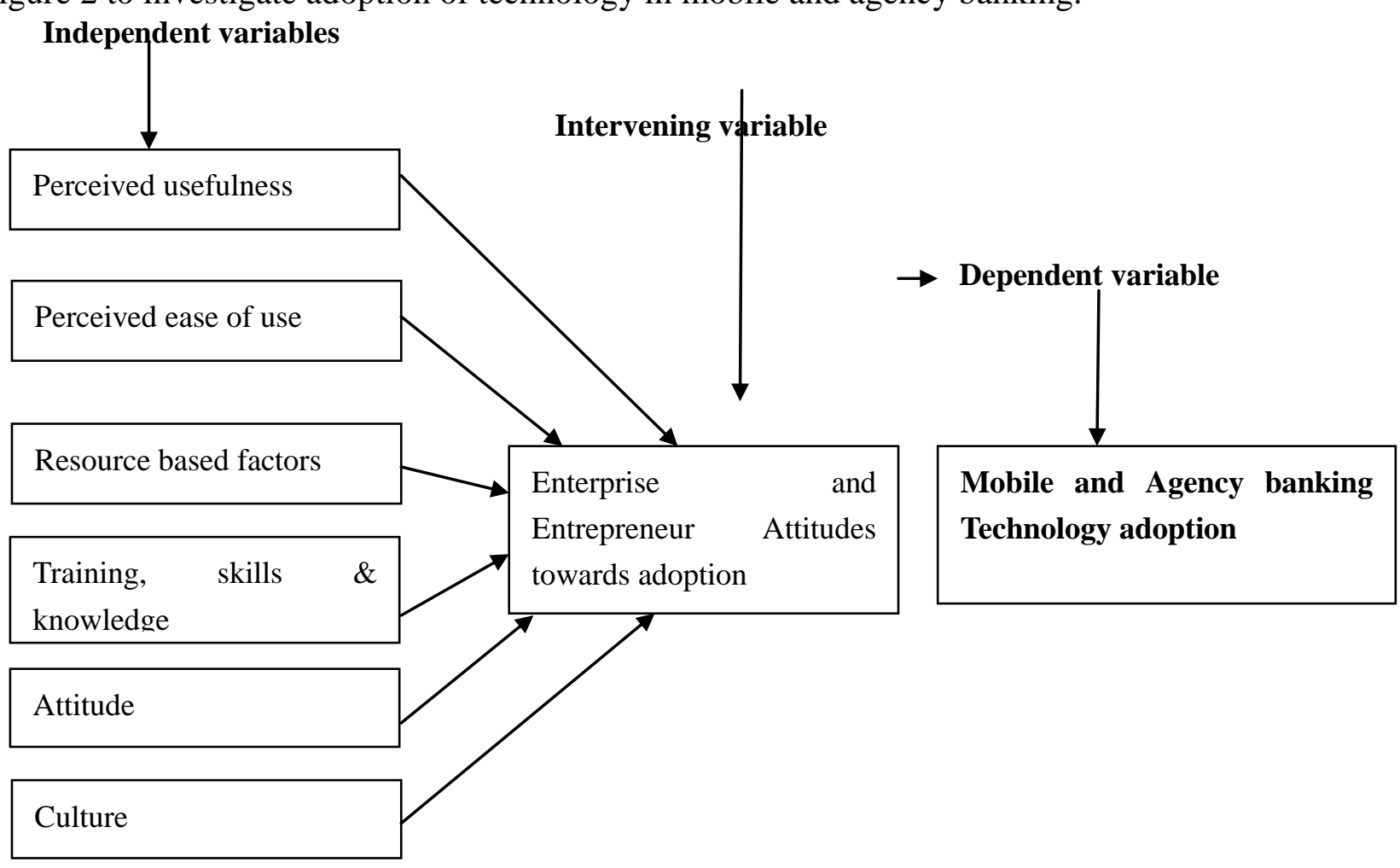

\section{Figure 2: The conceptual model}

This study is based on Schumpeter's theory that entrepreneurs both create and commercially exploit new knowledge which hitherto did not exist in the economic system and that have far 
reaching effects throughout the whole economy. Such innovations also challenge the existing order (Glancey and McQuaid, 2000). Schumpeter saw innovation as fundamental to the entrepreneurial process of wealth creation and entrepreneurs as individuals who sought monopolies based on some innovation (Wickman, 2006). Entrepreneurs must do something new or there is no point in their entering a market. To Schumpeter, innovation encompasses any new way of doing something so that value is created. Innovation can also mean a new product or service, but can also include a new way of delivering an existing product or service so that it is cheaper or more convenient for the user (Wickman, 2006). Bank and mobile service providers saw an opportunity in the unbanked rural population and went on to exploit this opportunity by creating agencies down to the village level. This gave the banks, mobile service providers and the SME sector a chance to create new possibilities, the chance to offer the market a fresher, more affordable pie (Venter and Rwigema, 2004). In mobile and agency banking, the transformation process was the services offered by the agents of financial management to the SMEs through deposits, withdrawals and advancing loans the output is the SMEs growth or lack of it thereof. The study sought to compare the factors that cause differences in adoption of agency banking in the two rural areas of the study Likuyani and Karatina.

\section{Methodology}

Both districts under study are relatively new after being hived off from earlier larger districts. Likuyani district is found on the western region of Kenya in Kakamega County while Karatina is found in the central region of Nyeri County in Kenya. In Likuyani district many residents are small scale maize farmers who also keep Cows for milk and earn an extra income from casual labor, chicken rearing and vegetable farming (Matere, 2010). Karatina municipality has a total population of six thousand, eight hundred and fifty two $(6,852)$ all classified as urban according to the 2009 census, GoK (2009). The economic activities here are mainly small scale tea, coffee, dairy and horticultural farming. The research design for this study was a comparative survey. The survey was used to obtain the views Ng'ang'a, et al (2009) of the banking agents and their customers on whether they use the services of the banking agents and the effect this may have had on their businesses on the part of the entrepreneurs. The study sample was obtained from SMEs in the two study areas yielding a sample of 80 SMEs and 20 agency banks which were selected proportionately and multistage and mixed sampling strategies. Stratified sampling was used where the SMEs under study were classified as either using banking agents or not. Clustered sampling ensured representation of all groups of SMEs in the total population (Zikmund, 2005). Systematic sampling was then employed to determine which particular SMEs would be used in the sample. This was done by arranging the SMEs that use the services of banking agents according to the place of operation, that is, the different market centers in the districts, then every third element was picked to form the sample needed. Primary data was collected using a questionnaire. The results obtained from Likuyani and Karatina districts were then compared. 


\section{Study Findings}

\section{Background information of respondents}

The background information was a prerequisite in explaining certain variables such as culture, economic and duration of being in the business. Respondents' age helped to establish the age bracket of entrepreneurs in the agency banking business and therore the propensity to adopt technology. This was useful is finding out whether the myth that the youth adopt new technologies faster than older people is applicable in this sector. From the study findings, in Likuyani most of the respondents (30.1\%) were aged between 25-40 years while in Karatina most of the respondents (47.6\%) were aged between 31-40 years. The bank agents in Karatina had $21.1 \%$ aged between $31-40$ years while in Likuyani $36.8 \%$ were aged between 25-30 years.

Respondents were asked to indicate their gender to establish whether there is any particular gender that may have invested more in agency banking in the two districts. In Karatina, of the bank agents $33.3 \%$ were males and $66.7 \%$ were females while Likuyani district had $50 \%$ males and $50 \%$ females. On the other hand, the SMEs in Karatina had $53.3 \%$ being females and $46.7 \%$ males while Likuyani had $72.2 \%$ males and $27.8 \%$ females. The results show that among the banking agents, the female agents in Karatina were twice those of the males while in Likuyani there was an equal number for both genders. Likuyani also had a higher number of agents than Karatina. SMEs in Likuyani were however fewer than those in Karatina with males operating most of them.

Most of the SMEs owners were certificate holders with Likuyani having $22.2 \%$ at certificate level, $3.2 \%$ having a diploma, $1.6 \%$ a degree and $1.6 \%$ a master's degree. Certificate holders were $42.9 \%$ in Karatina, $16 \%$ diploma and $2 \%$ had a degree. Some of the bank agents in Karatina $27.8 \%$ had diploma while in Likuyani most of them $38.9 \%$ had certificate. There were no agents with degree and above in both districts. From the findings $47.4 \%$ of the respondents in Likuyani and $36.8 \%$ of respondents in Karatina indicated that to be a bank agent one needed to own an existing business. According to $10.5 \%$ of respondents in Likuyani and $5.3 \%$ in Karatina, they needed to have a particular amount of capital to be allowed to act as bank agents.

\section{Adoption of Agency Banking}

Most of the respondents who operated the SMEs had bank accounts $87.8 \%$ in Karatina and $94.4 \%$ in Likuyani with only $5.6 \%$ in Likuyani and $12.2 \%$ in Karatina did not have bank accounts. In both districts most of the SME owners 39.7\% in Karatina and 24.1\% in Likuyani have had a bank account for between 1-5 years as shown in figure 3. 


\section{Macrothink}

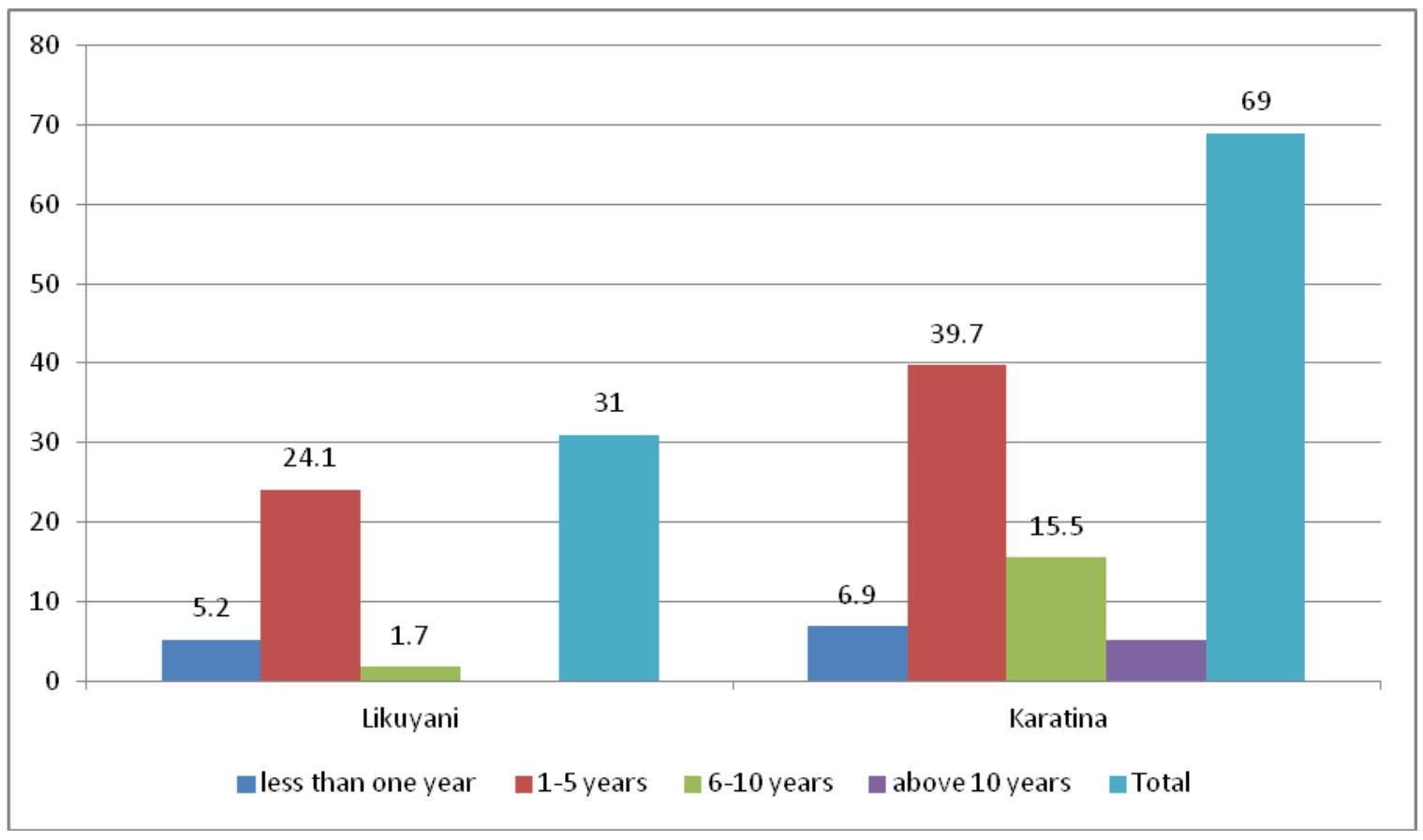

\section{Figure 3: Duration of having bank account}

It can be observed that SMEs served by the bank agents had bank accounts which enabled them to receive services offered by the agents. This is further evidenced by the duration that the SMEs have been in operation. Interesting to note was that there were no SMEs above 10 years in Likuyani while Karatina had SMEs that had existed for more than ten years. This implies that majority of SME owners open accounts for their businesses as soon as they start them.

Majority of the agents represented Equity bank with $36.9 \%$ in Karatina and $31.6 \%$ in Likuyani. Co-operative bank had the second highest representation in Likuyani district with $10.5 \%$ while Karatina had KCB with an equal share of $10.5 \%$. Some of the agencies in Likuyani district, 5.3\% represented both Equity bank and KCB. The phenomenon of dual representation was not observed in Karatina district. The results are shown in figure 4. 


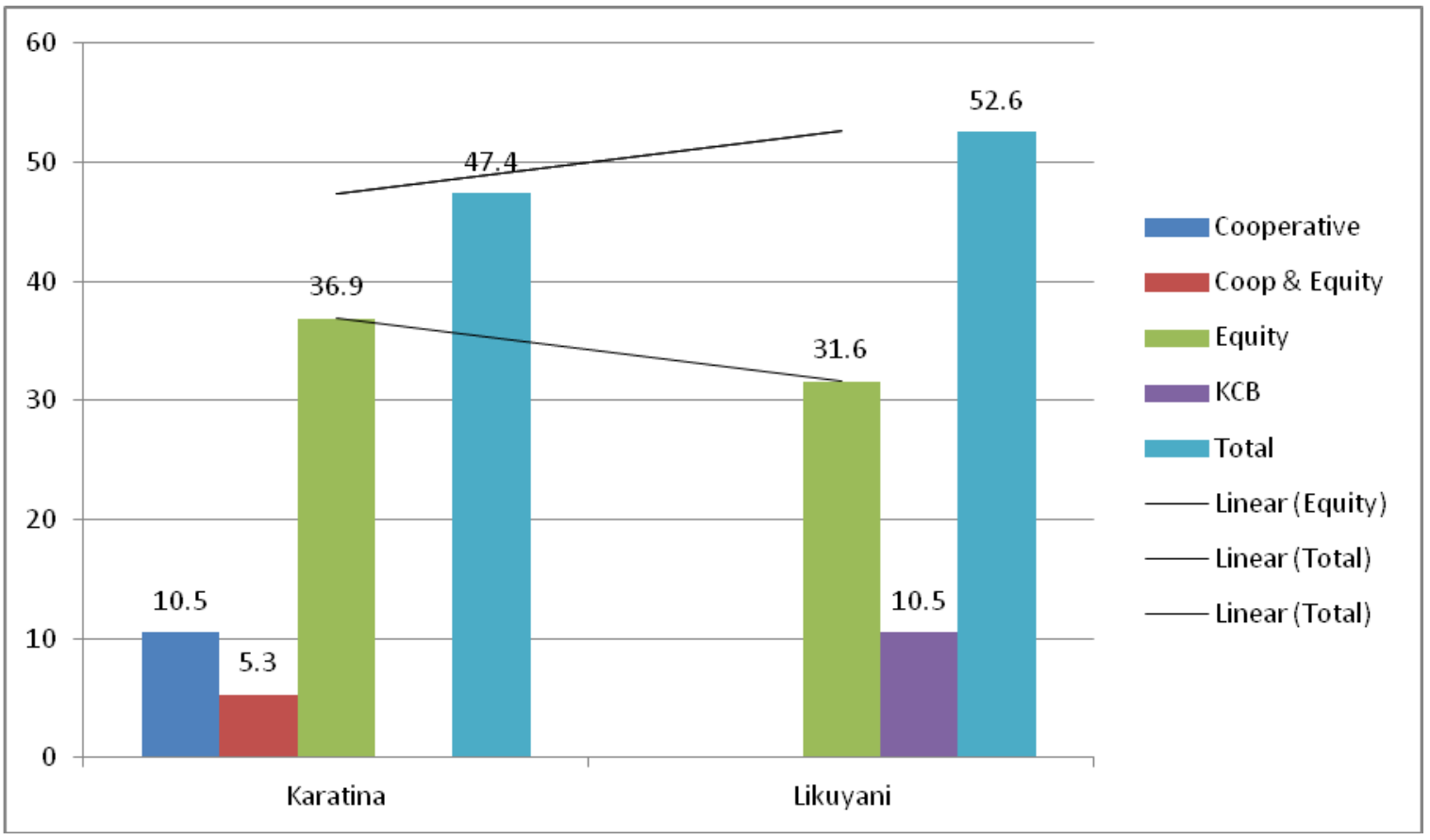

\section{Figure 4: Bank Represented}

Majority of the agencies used Safaricom mobile service provider for their transactions with the banks with $42.1 \%$ of agents in Likuyani and $26.3 \%$ in Karatina using it exclusively. The rest of the agencies used Safaricom together with other mobile networks such as orange, Airtel and Yu.

In Karatina most (15.8\%) of the bank agent's customers were small business owners while in Likuyani the highest frequency $(21.1 \%)$ were employees of NGOs. However, the customer base for the agents constituted government employees, SME owners as well as NGO employees where $26.3 \%$ of both Likuyani and Karatina agents had their response indicating so.

The study sought to find out from the agents the services they offered to their customers. The results show that $21.1 \%$ of the agents in Karatina offered deposit services and $10.5 \%$ offered loan services unlike in Likuyani where $47.4 \%$ offered withdrawal services and 5.5\% deposits. Agents in Karatina district also offered money transfer services which were not offered by agents in Likuyani district. This is as shown in figure 5. 


\section{Macrothink}

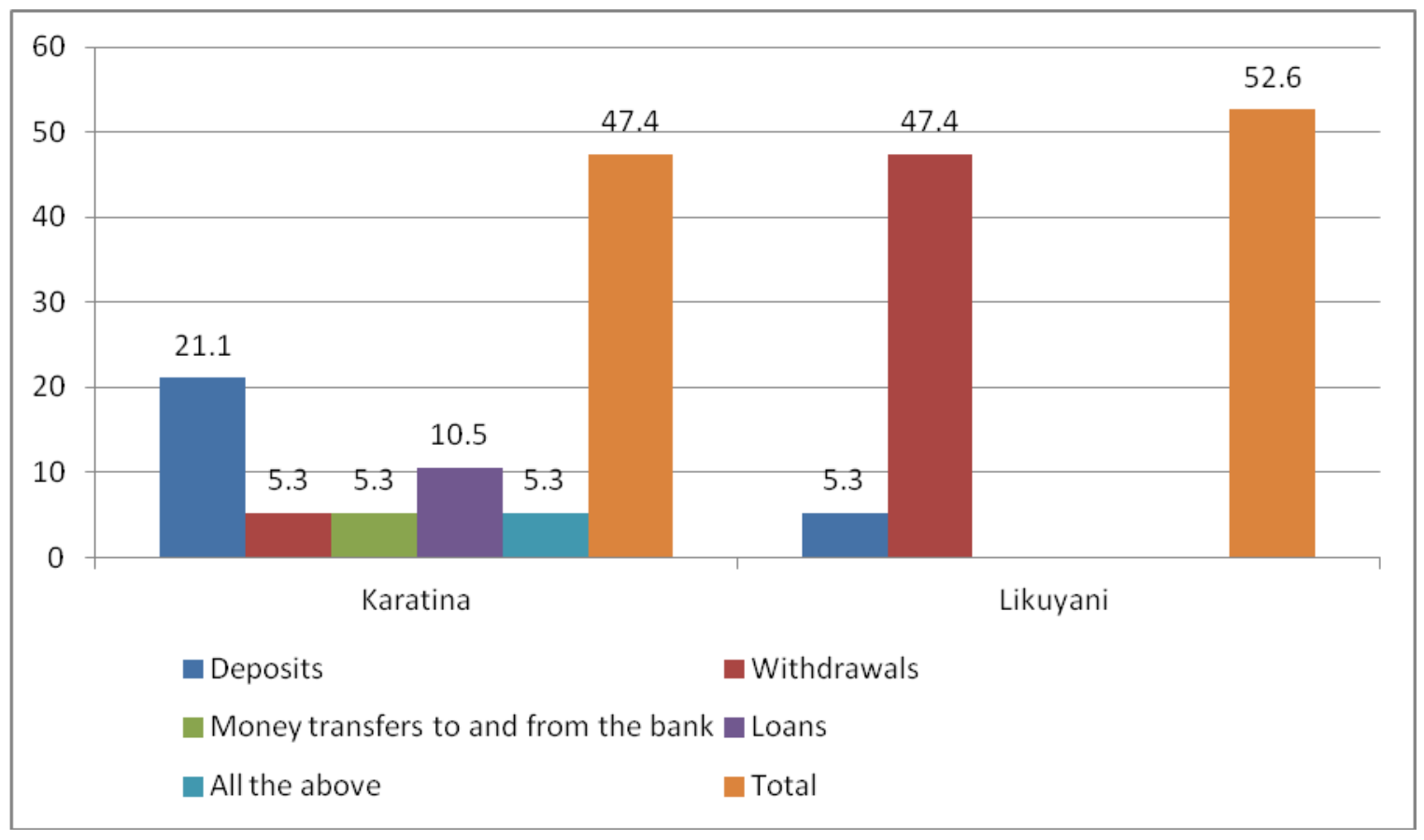

Figure 5: Services offered by bank agents

These results suggest that only 5.3\% of SMEs in Karatina use all services (Deposit, Withdrawls, Money transfer to and from bank, and loans) while in Likuyuni none. This confirms the problem in technology adoption and use of the available services in the both regions.

\section{Challenges experienced in technology and agency banking}

The survey revealed that challenges faced in technology and agency banking adoptions are mainly competition and resources in both Karatina and Likuyani as shown in figure 6 . 


\section{Macrothink}

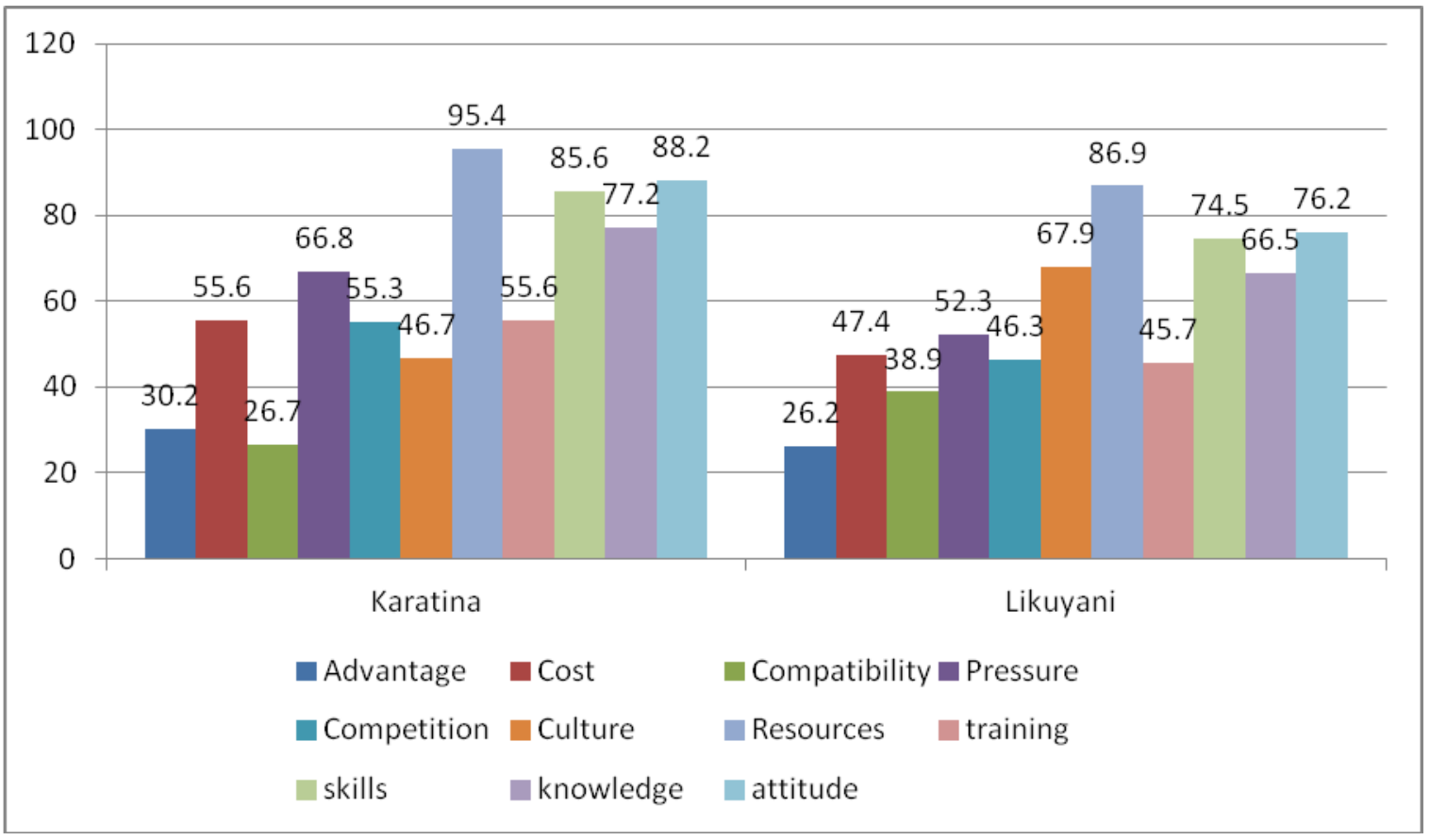

Figure 6: Challenges experienced in technology and agency banking

The survey results means that the main challenges faced in the two regions are; competition, lack of resources, compatibility, attitude and lack of knowledge.

\section{Discussion of Findings}

The study results indicate that competition, lack of resources, inadequate training, skills and knowledge of available technological services, compatibility with existing services and technologies and culture tends to affect the extent to which SMEs adopt mobile and agency baking technology. Most of owners in Karatina and Likuyani, managers and of SMEs are not aware of new technologies. They also use only simple straightforward features of their mobile devices. The education level of the agents in both districts was at the lower level of the education continuum. This finding is supported by Jean-Eric (2004) who observed that technology adoption climates in developing countries are first hampered by weaknesses of other key elements of knowledge-based economies as defined in the World Bank Institute (WBI) four pillar frameworks, namely levels of educational attainment, the business environment and the information infrastructure. Educational levels are low in developing countries, and, this is a significant barrier to the development and diffusion of innovation in these countries. Jean-Eric (2004) noted that tele-density remains weak in a number of developing countries, inferior to what may be considered the minimal threshold for take-off (around 30 percent). Progress made with mobile phone technology can lead to rapid improvements in connectivity, however it does not solve the necessity for greater internet penetration something which remains quite low in most developing countries. Infrastructural needs for innovation in developing countries are, however, not limited to telecommunications. Road and other transport infrastructure are of primary importance, as well as sanitation, water, and other systems (Jean-Eric, 2004). Molla and Licker (2005) observed that the social, 
cultural and economic conditions of developed and developing countries are different and therefore, developed countries technology adoption model cannot be applicable for developing countries without modifications. Based on the study findings, the factors that have more influence on M-banking adoption by SMEs can be categorized as internal factors that include organizational capabilities, perceived benefits and perceived risks on the one hand and external factors that include ICT industry preparedness, financial institutions readiness and pressure from other institutions on the other hand.

\section{Internal Organizational Factors}

Organizational capabilities may take several forms including human capital, IT literacy, and slack resources. Yap et al., (1992) mention that SMEs are regarded as 'poor' in human, financial and material resources and that hinders them to adopt ICTs. Hence, SMEs with more IT experience and IT in use are more likely to adopt technology based innovations. Technological readiness of SMEs is important for e-commerce adoption (Zhu et al., 2006) and it includes not only physical assets, but also human resources as human resources are complementary to physical asset (Mata et al.1995). Iacovou et al (1995) measured organizational readiness through financial resources and technological resources. Zhu and Kraemer (2005) mentioned that, organizational readiness includes infrastructure, relevant systems, and technical skills. Although, the definition of organizational readiness differs in literature, it is generally agreed that organizational readiness have strong influence on SMEs' technologies adoption (Zhu et al. 2003, 2004). Due to importance of human capital, IT and financial capital in determining technology adoption and use in any organization, Zhu et al (2004) included organizational capabilities as one of the factors in M-banking adoption by SMEs. This would explain the differential performance in mobile and agency banking technologies in Karatina and Likyuani given the difference SMEs organizational capabilities in the two areas.

Customers in both regions considered the benefits of agency banking before deciding to use it. Numerous studies indicate that perceived benefit is a key reason for technology adoption. Benefits m-bannking to SMEs includes lower administrative cost (Quayle, 2002); increased internal efficiency (Hawkins and Prencipe, 2000); improved relationship with business partners (Poon and Swatman, 1997); improved competitiveness (Fraser et al 2000) and improved quality of information (Kaplan and Sawhney, 2000). Mehrtens. Et al (2001) ranked perceived benefits as main factors for small firms' Internet adoption. M-banking provides benefits to SMEs like 24/7 access to bank account, fund transfer and bill payment. M-banking also widens scope of financing from both local and global players (UNCTAD, 2001). It can therefore, be conclude that perceived benefits is one of the main factors for M-banking/agency adoption by small firms and a lot of efforts may have to be made to educate the would be or potential adopters on all of them.

Perceived risk this was one of the cause of poor technology adoption in Likuyani and Karatina mobile and agency banking. Security, Trust and Perceived Credibility: 'Perceived 
risk is the consumer's subjective expectation of suffering a loss in pursuit of a desired outcome' (Wang et al., 2003). Perceived risk is multi-dimensional in nature and captures performance, physical, financial, psychological, social loss and time (Greatorex and Mitchell, 1994) and therefore, difficult to capture objectively (Pavlou, 2001). Akinci et al. (2004) found that lack of confidence, security, reliability and privacy issues are main concerns of mobile banking customers. The components of mobile/online security are trust, confidence, reliability, risk on mobile transactions and reputation of mobile financial service providers. Security issues arise due to disruption of the operating system, or interrupted supply of the internet/communication (Min and Galle, 1999). In case of web based transactions, trust on service providers as well as on the system is important (Lee and Turban, 2001). Wang et al (2003) found the perceived credibility is most determining factors in Internet banking adoption. Perceived credibility is impersonal in nature, and captures reputation, information and economic reasoning ( $\mathrm{Ba}$ and Pavlou, 2002). It reflects consumers' perception regarding the online transaction's security and trust issues (Wang et al., 2003). Therefore, this research adopts perceived credibility as a construct in the adoption of agency banking and would readily explain the differential adoption in the two rural areas depending on the extent of risk taking or averseness by the SMEs potential adopters.

\section{External Environmental Factors}

External factors together with the internal ones determine the level of technological innovation adoption. The relevant external factors that influence adoption of mobile and aency banking technologies include ICT Industry preparedness. In both regions, Likuyani and Karatina, the SMEs were not prepared to switch fully to agency banking. ICT infrastructure includes telecommunication network, Internet connectivity and availability of computer both hardware and software. Technological environment, both electronic and telecommunication, where a particular firm operates have influence on ICT adoption (Dholakia and Kshetri, 2004). Shortage of information technology infrastructures act as barriers for sustaining growth of online commerce (Chircu and Kauffman, 2000). Hence, we conclude that M-banking adoption by SMEs depends on ICTs industries readiness which was inadequate in both study sites. On the financial institutions readiness, the dominant banks offering agency banking were Equity bank and Cooperative banks in the both regions, this shows that other financial institutions were not ready to invest heavily into agency banking in both regions. M-banking offers benefit for banks as well their customers. M-banking is described as 'wallet sharing' for both financial institutions and SMEs (Sato and Hawkins, 2001). If any banks have online channel for providing banking services, and as building these online channel requires huge amount of investment, therefore, bank certainly would ask their customers to use online channel. Zhu et al (2003) mentioned that lack of trading partner readiness is significant adoption inhibitor. Trading partner readiness encourages small firms to adopt ICT and electronic commerce (McCole \& Ramsey, 2005) and same expected to apply in M-banking adoption by SMEs. Finally, pressure from other institutions was not much in both Karatina and Likuyani. The pressure for SMEs and financial institutions to adopt agency banking is not much due to low competition and poor governmental and NGOs support. 
Institutions form a social structure that creates a high degree of reliance (Scott, 2001). King et al., (1994) provides a list of institutions including government, governmental institutes, development agencies, educational institutes, and business association. Pressure may emerge due to competition and as well as from regulation. Institutions can exert pressure to SMEs to adopt m-banking through many ways including enacting laws, providing training, subsidy, and knowledge deployment. DiMaggio and Powell (1983) observe that institutional pressure can be coercive, normative and/or mimetic. Financial institutions can also influence SMEs regarding use of their online channel for banking as it is beneficial to both. The difference of technology adoption between Karatina and Likuyani can also be explained by the cultural factors because more women in Karatina have businesses unlike in Likuyani where majority were the male. This means that their cultures influence women involvement in business ventures.

\section{Conclusion and way forward}

Despite introduction to mobile banking such as Mpesa and agency banking, most Kenyans in rural areas find full technology adoption anathema. Despite the wide array of mobile and agency banking services available, the main services offered are cash deposits and withdrawals. The main challenges to adoption of mobile and agency banking technology in Karatina and Likuyani are cost related, compatibility, lack of institutional pressure, competition between adopters, culture related, inadequate resource, inadequate relevant training, skills, knowledge and attitudinal which are categorized as internal and external factors to the SME. To facilitate and improve mobile and agency banking technology adoption in rural Kenya and other developing countries, there is need to;

i) Address the internal factors through awareness creation, training, improving organization/SME capability, enhance and assure security, reliability, confidence and improve risk taking propensity by SME potential adopters.

ii) Address external factors through policy framework, improved ICT and Telecommunication infrastructure, integrated and persistent institutional pressure and availing requisite human and financial capital and other resources that would support early SME adopters for the growth/diffusion of Mobile and Agency Banking technology adoption, improved individual income, SME performance and societal and national economic development.

\section{References}

Arbuckle, J. A. (1995). Amos 16 Users Guide. http://amosdevelopment.com. Accessed $17^{\text {th }}$ November 2012.

Ba, S. and P. A. Pavlou (2002).Evidence of the effect of trust building technology in electronic markets: price premiums and buyer behavior. MIS Quarterly 26(3): 243-268.

Besley S and Brigham, E. F (2005). Essentials of Managerial Finance. $13^{\text {th }}$ ed. Thomson Southwestern, USA. 
British Educational Communications and Technology Agency (BECTA) (2003). What

Research Says about Barriers to the Use of ICT in Learning. Retrieved from www.becta.org.uk/research. on $17^{\text {th }}$ November 2012.

Bertrand, M. and Bouchard, S. (2008) Applying the Technology Acceptance Model to VR with people who are favorable to its usell

Bigum C. (2000). Solutions in Search of Educational Problems: Speaking for

Computers in Schools. [Electronic Version] Educational Policy, 12 (5), 586- 596.

Chircu, A. M. and Kauffman, R. J. (2000). Limits to value in electronic commercerelated

IT investments. Journal of Management Information Systems 17(2): 59-80.

Davis, F. (1989). Perceived Usefulness, Perceived Ease of Use, and User Acceptance of Information Technology. MIS Quarterly, 13(3): 319-340.

DiMaggio, P. J. and Powell, W. W. (1983). The iron cage revisited: Institutional isomorphism and collective rationality in organizational fields. American

Sociological Review 48: 147-160.

Dholakia, R. R. and Kshetri, N. (2004). Factors Impacting the Adoption of the Internet among SMEs. Small Business Economics 23: 311-322.

Financial Sector Deepening Trust (FSD). (2011). Agency and Mobile Banking in

Kenya. Retrieved from www.fsdkenya.org on 10/12/2012

Jean-Eric Aubert (2004), Promoting Innovation in Developing Countries: A Conceptual

Framework . Jean-Eric World Bank Institute

Gibb, A, A (1988). Stimulating Entrepreneurship and New Business Development. ILO. Geneva

Glancey,K. S and McQuaid, R. W. (2000). Entrepreneurial Economics. Macmillan, Basingstoke and St. Martin's Press, New York.

GOK (1992). Sessional Paper No. 2 of 1992 on Small Enterprise and Jua Kali Development in Kenya. Government Printers. Nairobi.

GoK.(2009). Population and Housing Census Highlights, Kenya Bureau of National Statistics, Nairobi: Government Printer.

Greatorex, M. and V. W. Mitchell (1994). Modeling consumer risk reduction preferences from perceived loss data. Journal of Consumer Marketing 15(4):

669-685.

Hair, J.K.; Black C.W.; Babin, B.J., and Anderson R.E. (2006) Multivariate Data analysis sixth edition Pearson, Prentice Hall. New Delhi.

Hawkins, R. and Prencipe, A. (2000). Business-to-Business E-Commerce in the UK: A Synpaper of Sector Reports Commissioned by the Department of Trade and Industry. DTI, London.

Horne, J.C.V and Wachowicz, J.M. (2005). Fundamentals of Financial Management.

Horne Publishers, Prentice Hall. England.

International Fund for Agricultural Development (IFAD). (2011). Enabling poor rural people to overcome poverty in Kenya. Rome, Italy. Retrieved from $\quad$ www.ifad.org on $19 / 12 / 2012$.

Kinyanjui, K. (2011). Agency banking runs into hurdles in Kenya, in the Business daily. June 142011 
Kaplan, S. and Sawhney, M. (2000). E-hubs: The new B2B marketplaces Harvard Business Review May-June (97-103).

Lee, M. K. O. and Turban, E. (2001). A trust model for consumer Internet shopping. International Journal of Electronic Commerce 6(1): 75-91.

Matere, Z. (2010). LEO: Bridging the Digital Divide one village to another and the world. Retrieved from http://arc.peacecorpsconnect.org on 20/01/2012

Mulupi, D. (2011). Kenya: Taking Mobile Money a Step Further. Nairobi. Retrieved from www.audiencespace.org field blog. Retrieved: 17 $7^{\text {th }}$ November 2012.

Mas, Ignacio (2010), Mobile Payments Go Viral: M-PESA in Kenya, in Yes Africa Can:

Success Stories from a Dynamic Continent, World Bank, Washington D.C.

McCole, P. and Ramsey, (E. 2005). A profile of adopters and non-adopters of eCommerce in SME professional service firms. Australasian Marketing Journal 13(1): 36-48.

Molla, A. and Licker, P. S. (2005). E-commerce adoption in developing countries: a model and instrument. Information \& Management 42: 877-899.

Ng'ang'a, S.I.; Kosgei, Z.K.; and Gathuthi, E.W. (2009). Fundamentals of Management

Research Methods - Nairobi: Macmillan Kenya (Publishers) $\quad$ Limited. ISBN 978 9966343451

Nysveen, H.; Pedersen, P.E. and Thorbjornsen, H. (2005). Intentions to Use Mobile Services: Antecedents and Cross-Service Comparisons. Academy of Marketing

Science; Journal; Sumer 2005; 33, 3; ABI/INFORM Global.

Pavlou, P.A. (2001). Consumer intentions to adopt electronic commerce- incorporating trust and risk in the technology acceptance model. in proceeding of the Diffusion Interest Group in Information Technology Conference (DIGIT2001) New Orleans, LA. Pettigrew, N.; Taylor, J.; Simpson, C.; Lancaster, J.; and Madden, R. (2007). Live now,

save later? Young people saving and pensions.Norwich, UK: Department of

Work and Pensions (Research report No. 438)

Rwigema H, and Venter R (2004). Advanced Entrepreneurship. Cape Town:

Oxford University Press.

Sato, S. and Hawkins, J. (2001). Electronic finance: an overview of the issues. BIS Papers 7: 1-12.

United Nations Conference on Trade and Development (UNCTAD), B. P. (2001). Improving Competitiveness of SMEs in Developing Countries: Role of Finance, including E-Finance to Enhance Enterprise Development, A Paper Presented in Expert Group Meeting, Geneva 22-24: 1-19.

United Nation Development Programme (UNDP )(2009), "Human Development

Report 2009, Overcoming barriers: Human Mobility and Development" Retrieved from, hdr.undp.org/en/reports/global/hdr2009/ on 17 $7^{\text {th }}$ November 2012.

Wang, Y. S.; Wang, Y. M. et al. (2003). Determinants of user acceptance of Internet

Banking: An empirical study. International Journal of Service Industry

Management 14(5): 501-519.

Yap, C. S., C.; Soh, P. P.; et al. (1992). Information Systems success factors in small business. International Journal of Management Science 1992(5): 6. 


MlMacrothink

Zikmund, W. G. (2003) Business Research Methods, $7^{\text {th }}$ Ed. USA, South-Western.

Zhao, Y. and Frank, KA (2003). Factors Affecting Technology Uses in Schools: An Ecological Perspective [Electronic Version]. American Educational Research Journal, 40(4), 807-840.

Zhu, K.; Kraemer, K. L. et al. (2004). Information technology payoff in e-business environments: An international perspective on value creation of e-business in the financial services industry. Journal of Management Information Systems $21(1)$ : 17-54.

Zhu, K. and Kraemer, K. L. (2005). Post-adoption variations in usage and value of ebusiness by organizations: Cross-country evidence from the retail industry. Information Systems Research 16(1): 61-84.

Zhu, K., Kraemer K. L, et al. (2006). The Process of Innovation Assimilation by Firms in Different Countries: A Technology Diffusion Perspective on E- Business."

Management Science 52 (10): 1557-1576. 